\title{
PENGARUH PENERAPAN LATTICE MULTIPLICATION METHOD UNTUK MENGATASI KESULITAN MENYELESAIKAN OPERASI PERKALIAN
}

\author{
Farlina Wardiyana Fatmala ${ }^{1}$, Pujilestari ${ }^{2}$ \\ ${ }^{1,2}$ Pendidikan Matematika, FPMIPA IKIP Mataram \\ farlinawardiyanafatmala@gmail.com
}

\begin{abstract}
Abstrak: Banyak siswa SMPN 7 Pujut mengalami kesulitan menyelesaikan operasi hitung perkalian. Oleh karena itu peneliti melakukan penerapan lattice multiplication method untuk dapat mengatasi permasalahan tersebut. Tujuan dari penelitian ini yaitu untuk mengetahui pengaruh penerapan lattice multiplication method untuk mengatasi kesulitan menyelesaikan operasi perkalian pada siswa kelas VIII SMPN 7 Pujut. Metode yang digunakan dalam penelitian ini adalah metode penelitian pra-eksperimen dengan desain penelitian one group pre and posttest design. Sampel penelitian ini merupakan perwakilan siswa dari setiap rombel pada kelas VIII SMPN 7 Pujut yang direkomendasikan oleh guru matematika karena mengalami kesulitan menyelesaikan operasi perkalian yang berjumlah 20 orang siswa. Berdasarkan hasil penelitian yang dianalisis menggunakan uji $t$ (paired sample $t$ test) berbantuan SPSS 16.0 diperoleh data $t_{\text {hitung }}=0,000$ dan dengan $a=5 \%=$ 0,05 diperoleh $t_{\text {tabel }}=1,729$ yang artinya $t_{\text {hitung }} \leq t_{\text {tabel }}$. Hasil tersebut menunjukkan bahwa terdapat perbedaan yang signifikan antara hasil tes sebelum diterapkan metode perkalian latis (pretest) dengan hasil setelah diterapkannya metode perkalian latis (posttest) yang diperoleh siswa. Dengan demikian dapat disimpulkan bahwa terjadi penolakan terhadap $H_{0}$ sehingga $H_{\mathrm{a}}$ diterima dimana $H_{\mathrm{a}}$ berbunyi: ada pengaruh penerapan lattice multiplication method untuk mengatasi kesulitan menyelesaikan operasi perkalian pada siswa kelas VIII SMPN 7 Pujut.
\end{abstract}

Kata Kunci: Lattice Multiplication Method, Kesulitan Menyelesaikan Operasi Perkalian

\section{PENDAHULUAN}

Pendidikan merupakan upaya untuk membentuk sumber daya manusia yang dapat meningkatkan kualitas kehidupannya. Selain itu melalui pendidikan akan dibentuk manusia yang berakal dan berhati nurani yang sangat diperlukan dalam menguasai dan mengembangkan ilmu pengetahuan dan teknologi, sehingga mampu menghadapi persaingan global (Astrawan, 2014).

Hingga kini pendidikan masih diyakini sebagai wadah dalam pembentukan sumber daya manusia yang diinginkan. Melihat begitu pentingnya pendidikan dalam pembentukan sumber daya manusia, peningkatan mutu pendidikan merupakan hal yang wajib dilakukan secara berkesinambungan guna menjawab perubahan zaman. Masalah peningkatan mutu pendidikan tentulah sangat berhubungan dengan masalah proses pembelajaran. Menurut Lubis (dalam Rachman, Syahrir dan Lestari, 2014) peran guru sangat penting dalam proses pembelajaran karena berhadapan langsung dengan peserta didik, oleh karena itu seorang guru harus berkualitas agar berkemampuan untuk meningkatkan mutu pendidikan. Proses pembelajaran yang sementara ini dilakukan di lembaga-lembaga pendidikan kita masih banyak yang mengandalkan cara-cara lama dalam penyampaian materinya. Sehingga dalam rangka meningkatkan kualitas pembelajaran yang lebih baik, diperlukan adanya perbaikan dalam proses pembelajaran yang dilakukan di sekolah.

Salah satu cara yang bisa dilakukan agar proses pembelajaran dapat berjalan dengan baik yaitu dengan menggunakan metode 
pembelajaran yang tepat. Hal ini sejalan dengan pendapat Jauhar (dalam Lestari, 2017) yang menyatakan bahwa sebuah proses pembelajaran yang efektif memerlukan teknik, metode, strategi, dan pendekatan yang tepat. Seperti yang diungkapkan oleh Susilo dan Khadibah (2013) yang mengatakan bahwa penggunaan metode pembelajaran yang tepat dapat menjadikan siswa mencapai prestasi belajar yang tinggi dan dapat mengembangkan potensi yang tersimpan dalam dirinya, sehingga mereka akan lebih termotivasi untuk belajar matematika dan tidak menganggap matematika sebagai pelajaran yang sulit bahkan menganggap bahwa pelajaran matematika merupakan pelajaran yang menyenangkan.

Matematika merupakan mata pelajaran yang dipelajari pada setiap jenjang pendidikan mulai dari SD, SMP, SMA sampai jenjang perguruan tinggi. Menurut Sutarto dan Syarifuddin (2013), matematika di jenjang sekolah seperti Sekolah Dasar (SD), Sekolah Menengah Pertama (SMP), dan Sekolah Menengah Atas (SMA) disebut matematika sekolah. Matematika sekolah memiliki peranan yang sangat penting untuk memenuhi kebutuhan praktis dan memecahkan masalah dalam kehidupan sehari-hari siswa. Dengan adanya matematika, siswa dapat berhitung, dapat mengumpulkan, mengolah, dan menyajikan data. Selain itu, dengan mempelajari matematika pengetahuan siswa juga semakin berkembang karena pola pikir yang lebih baik akan terbentuk dalam diri siswa sebagai akibat dari matematika yang melatih siswa untuk berpikir secara terstruktur.

Berdasarkan hasil wawancara singkat kepada 31 siswa pada satu kelas di SMPN 7 Pujut mengenai pandangan mereka terhadap matematika, penulis dapat simpulkan bahwa 29 dari 31 orang siswa tersebut menganggap matematika merupakan pelajaran yang sangat sulit karena banyak rumus dan selalu menghitung. Hal ini juga diyakinkan oleh pernyataan guru mata pelajaran mereka yang mengaku mengeluh karena banyak peserta didiknya yang tidak bisa operasi hitung dalam matematika terutama operasi perkalian, tidak memahami konsep operasi perkalian, bahkan perkalian bilangan satuan pun mereka tidak hafal. Guru tersebut menambahkan bahwa siswa-siswinya banyak sekali yang kesulitan dalam melakukan operasi perkalian baik perkalian puluhan dengan puluhan, ratusan dengan ratusan bahkan perkalian bilangan desimal pun mereka masih bingung. Selain melakukan wawancara dengan guru dan siswa, penulis juga melakukan tes perkalian sebagai bukti nyata terhadap kesulitan siswa terhadap operasi perkalian seperti pada Gambar 1.1 berikut.

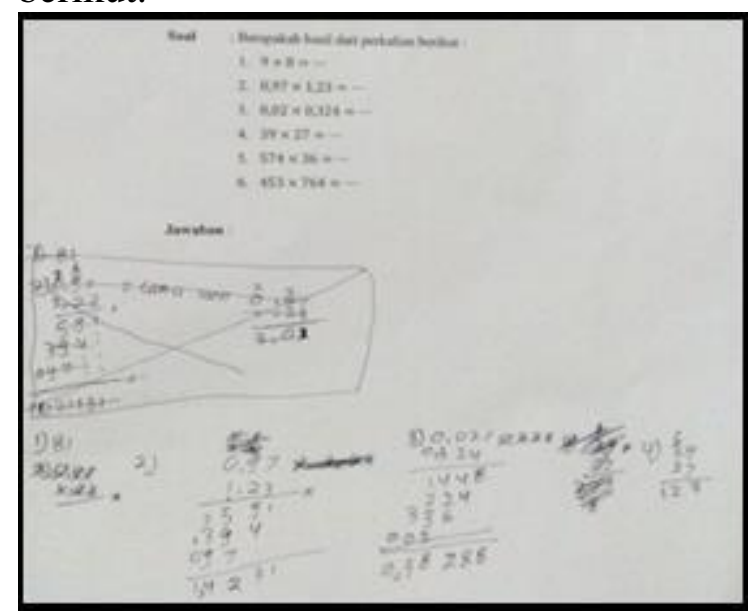

Gambar 1.1. Hasil Pekerjaan Siswa

Berdasarkan Gambar 1.1 di atas terlihat bahwa siswa tersebut menyelesaikan soal perkalian yang diberikan menggunakan konsep perkalian bersusun seperti yang sering diajarkan guru selama ini. Jawaban siswa tersebut memperkuat kebenaran dari pernyataan guru mata pelajaran yang telah menyatakan bahwa ada siswanya yang tidak menghafal perkalian satuan seperti yang terlihat pada jawaban siswa nomor 1 . Soalnya yaitu $9 \times 8=$ ?. Seharusnya siswa menjawab 72 , tetapi siswa tersebut menjawab 81. Untuk jawaban selanjutnya, dapat dilihat pada gambar bahwa jawaban siswa tersebut juga masih kurang tepat. 
Dewasa ini, kita mengetahui bahwa untuk mengajarkan operasi perkalian khususnya pada jenjang SMP, guru cenderung mengajarkan siswa dengan menggunakan metode perkalian bersusun. Padahal jika kita mencari tahu lebih dalam lagi, banyak metode yang bisa kita terapkan pada siswa untuk menyelesaikan soal operasi perkalian. Metode-metode tersebut diantaranya metode jarimatika, metode perkalian latis, metode sempoa dan sebagainya. Salah satu metode yang menarik adalah metode perkalian latis.

\section{KAJIAN PUSTAKA}

\section{Lattice Multiplication Method}

Menurut Mujib dan Suparingga (2013) metode perkalian latis merupakan salah satu metode perkalian yang menarik karena disajikan dalam bentuk tabel yang memuat hasil perkalian. Hasil perkalian dua bilangan ditempatkan dalam tabel yang disusun berdasarkan satuan, puluhan, ratusan dan seterusnya. Menurut Zubaidah, Margiati, dan Kresnadi (2015) "Metode Lattice" adalah cara kisi-kisi dengan batang napier yang merupakan penyempurnaan cara kisi-kisi oleh Jhon Napier seorang Skotlandia pada sekitar akhir abad 16, cara menduakalikan yang banyak dipakai pada masa Renaissance, perkalian dengan jari, dan perkalian cara petani Rusia.

Cara kerja dari metode latis sangat sederhana yaitu menerjemahkan persoalan perkalian menjadi persoalan penjumlahan yang hasilnya telah tersusun rapi dalam sebuah tabel. Adapun langkah-langkah pelaksanaan metode kisi-kisi atau lattice.

Langkah 1. Buatlah sebuah tabel, kemudian letakkan soal dengan bilangan pertama berada di atas tabel dan bilangan kedua diletakkan di samping kanan tabel. Banyaknya kolom dan baris disesuaikan dengan soal.

Langkah 2. Kalikan semua angka dan letakkan pada masing-masing kotak.

Langkah 3. Jumlahkan angka-angka di dalam tabel searah diagonal.
Langkah 4. Untuk angka yang dua digit (hasil penjumlahan), jumlahkan digit puluhannya ke angka yang berada di depannya.

Seperti halnya metode perkalian yang lain, metode perkalian latis juga memiliki kelebihan dan kekurangan. Berikut ini kelebihan dan kekurangan metode perkalian latis menurut Zubaidah, Margiati, dan Kresnadi (2015).

a. Kelebihan metode lattice

Adapun kelebihan dari metode lattice ini yaitu:

1) Perhatian anak didik dapat dipusatkan, dan titik berat yang dianggap penting oleh guru dapat diamati.

2) Perhatian anak didik akan lebih terpusat pada apa yang didemonstrasikan, jadi proses anak didik akan lebih terarah dan akan mengurangi perhatian anak didik kepada masalah lain karemna terlihat hal yang baru.

3) Dapat merangsang siswa untuk lebih aktif dalam mengikuti proses belajar.

4) Dapat menambah pengalaman anak didik.

5) Bisa membantu siswa ingat lebih lama tentang materi yang disampaikan.

6) Dapat mengurangi kesalah pahaman karena pengajaran lebih jelas dan konkrit.

7) Dapat menjawab semua masalah yang timbul di dalam pikiran setiap siswa karena ikut serta berperan secara langsung.

b. Kekurangan metode lattice, adalah sebagai berikut:

1) Memerlukan waktu

2) Tidak dapat digunakan untuk menyelesaikan operasi perkalian satuan dengan satuan, sehingga untuk dapat menggunakannya siswa harus sudah menguasai perkalian satuan dengan satuan yaitu perkalian 1 sampai 10 .

3) Tidak semua siswa paham dengan metode kisi-kisi karena masih dianggap baru.

$\underline{\text { Kesulitan Operasi Perkalian }}$ 
Kesulitan operasi perkalian merupakan salah satu kesulitan yang dialami siswa dalam belajar matematika. Kesulitan operasi perkalian merupakan kondisi siswa yang mengalami kesukaran dalam melakukan operasi perkalian. Hal ini sejalan dengan pendapat Rahman, Nursalam, dan Tahir (2015) yang mengatakan bahwa kesulitan belajar matematika merupakan suatu kondisi dimana siswa mengalami kesukaran dalam kegiatan akademik. Kesulitan operasi perkalian merupakan bagian dari kesulitan belajar diskalkulia (dyscalculia) atau ketidakmampuan dalam belajar berhitung (Runtukahu \& Kandou, 2014). Menurut Runtukahu \& Kandou (2014) anak berkesulitan belajar operasi perkalian memperlihatkan berbagai variasi kesulitan belajar, mulai dari yang paling ringan sampai pada yang berat. Kesulitan yang dapat dianggap ringan dalam operasi perkalian dan yang sering dialami siswa yaitu kesulitan dalam melakukan operasi perkalian satuan yang dapat berdampak untuk perkalian yang lebih besar seperti perkalian puluhan dengan puluhan, perkalian ratusan dengan ratusan, perkalian puluhan dengan ratusan, bahkan perkalian terhadap bilangan desimal.

Kesulitan operasi perkalian merupakan salah satu kesulitan belajar matematika. Bagi anak berkesulitan belajar matematika yang kurang dalam keterampilan motorik dan spasial, untuk perkalian sebaiknya menggunakan metode yang bervariasi yang tidak monoton pada satu metode saja (Runtukahu \& Kandou, 2014). Seperti operasi bilangan lainnya, perkalian berguna untuk memecahkan masalah dalam dunia nyata. Oleh sebab itu, penguasaan keterampilan operasi perkalian sangatlah diperlukan.

\section{METODE PENELITIAN}

Metode penelitian yang digunakan dalam penelitian ini adalah metode penelitian kuantitatif dengan jenis penelitian eksperimental. Penelitian eksperimental merupakan salah satu jenis penelitian kuantitatif yang sangat kuat mengukur hubungan sebab akibat (Taniredja dan Mustafidah, 2012). Menurut Syaodih (dalam Thoifah, 2015) penelitian eksperimental dibagi menjadi 4 yaitu eksperimental lemah (praeksperimen), eksperimental murni (true eksperimental), eksperimental semu (quasi eksperimental), dan subjek tunggal.

Dalam penelitian ini, peneliti menggunakan penelitian eksperimental lemah (pra-eksperimen). Disebut pra-eksperimen karena penelitian ini mengandung beberapa ciri eksperimental, akan tetapi masih dalam jumlah kecil sehingga belum memenuhi syarat dari penelitian eksperimen (Suryabrata, 2010). Sedangkan desain penelitian yang digunakan dalam penelitian ini adalah one group pre and posttest design. Menurut Suryabrata (2010) one group pre and posttest design merupakan desain pra-eksperimen yang hanya menggunakan satu kelompok subjek dengan tahapan melakukan pengukuran, lalu diberikan perlakuan untuk jangka waktu tertentu, kemudian dilakukan pengukuran untuk kedua kalinya setelah diberikan perlakuan.

Dalam penelitian ini digunakan 1teknik untuk melakukan pengumpulan data yaitu teknik tes. Penelitian yang target datanya berupa keterampilan, kompetensi/kemampuan, inteligensi, dan bakat, lebih tepat menggunakan teknik tes (Musfiqon, 2012). Dalam penelitian ini teknik tes digunakan untuk mendapatkan data hasil belajar operasi hitung perkalian sebelum dan sesudah diterapkan metode perkalian latis. Sehingga intrumen penelitianya berupa lembar tes prestasi. Lembar tes prestasi berisi soal-soal yang berkaitan dengan operasi perkalian puluhan dengan puluhan, ratusan dengan ratusan, puluhan dengan ratusan, pecahan dengan pecahan, serta desimal dengan desimal. Soal yang digunakan untuk pretest dan posttest adalah sebanyak 10 butir soal berbentuk uraian.

Instrumen yang baik harus memenuhi dua persyaratan penting yaitu valid dan reliabel 
sebelum digunakan untuk mengumpulkan data dalam penelitian. Untuk melakukan 2 uji tersebut, peneliti menggunakan bantuan software Anates dalam melakukan perhitungannya. Selain untuk melakukan perhitungan uji validitas dan uji reliabilitas instrumen, dengan bantuan software Anates juga peneliti akan melihat dan mengetahui daya beda soal yang akan digunakan peneliti dan tingkat kesukaran dari soal tersebut.

Selanjutnya, teknik analisis data yang digunakan dalam penelitian ini disesuaikan dengan data diperoleh peneliti dan pendekatan penelitian yang digunakan. Hipotesis yang telah dirumuskan dalam penelitian ini akan diuji dengan statistik parametris yaitu menggunakan Paired Sampel t-test dalam software SPSS 16.0 for windows. T-test digunakan untuk menguji perbedaan rerata nilai dari dua kelompok data atau sampel. Terdapat 2 uji prasyarat sebelum melakukan analisis data atau pengujian hipotesis yaitu uji normalitas dan uji homogenitas. Oleh karena itu sebelum pengujian hipotesis dilakukan maka terlebih dahulu dilakukan pengujian normalitas data dan homogenitas data. Kedua uji prasyarat ini juga dilakukan dengan menggunakan bantuan software SPSS 16.0 for windows. Adapun kriteria dalam menguji hipotesis yaitu jika $t_{\text {hitung }} \leq t_{\text {tabel }}$ maka $\mathrm{H}_{\mathrm{a}}$ diterima dan $\mathrm{H}_{0}$ ditolak, sedangkan jika $t_{\text {hitung }} \geq t_{\text {tabel }}$ maka $\mathrm{H}_{\mathrm{a}}$ ditolak dan $\mathrm{H}_{0}$ diterima (Sugiyono, 2017).

\section{HASIL \\ PENELITIAN \\ DAN \\ PEMBAHASAN}

\section{Hasil Analisis Uji Coba Instrumen}

Lembar tes yang di uji coba oleh peneliti terdiri dari 15 soal operasi perkalian yang di analisis dengan menggunakan software Anates dengan hasil yaitu:

a) Hasil analisis uji validitas

\section{Tabel 3.1. Hasil Analisis Uji Validitas}

Jurnal Pendidikan Mandala

\begin{tabular}{|c|c|c|}
\hline Kriteria & Nomor Soal & Jumlah \\
\hline Valid & $\begin{array}{c}2,3,5,6,7,8,9, \\
10,11,12\end{array}$ & 10 \\
\hline Tidak Valid & $1,4,13,14,15$ & 5 \\
\hline
\end{tabular}

b) Hasil analisis uji reliabilitas

Hasil perhitungan koefisien reliabilitas 15 butir soal dengan menggunakan software Anates diperoleh nilai reliabilitasnya adalah 0,92 .

c) Hasil analisis tingkat kesukaran soal

Tabel 3.2. Hasil Analisis Tingkat Kesukaran Soal

\begin{tabular}{|c|c|c|}
\hline Kriteria & Nomor Soal & Jumlah \\
\hline $\begin{array}{c}\text { Sangat } \\
\text { Mudah }\end{array}$ & 1 & 1 \\
\hline Sedang & $\begin{array}{c}2,3,4,5,6,7,8, \\
9,10,11,12,13\end{array}$ & 12 \\
\hline Sukar & 14,15 & 2 \\
\hline \multicolumn{2}{|c|}{ Khusus untuk uji validitas, selain } \\
\hline
\end{tabular}
dilakukan validasi secara empirik, seluruh instrumen beserta komponen penunjang penelitian lainnya seperti RPP dan LKS dilakukan uji validitas isi oleh 2 ahli materi yang terdiri dari salah seorang dosen dan seorang guru mata pelajaran matematika. Berdasarkan uji validitas dari dua validator dinyatakan bahwa lembar tes, RPP, dan LKS adalah valid dan dapat digunakan untuk penelitian.

Hasil Analisis Data Pretest dan Posttest Tabel 3.3. Rekapitulasi Hasil Analisis Pretest dan Posttest

\begin{tabular}{|c|c|c|c|c|}
\hline \multirow{2}{*}{$\begin{array}{l}\text { Jenis } \\
\text { Tes }\end{array}$} & \multirow{2}{*}{$\begin{array}{l}\text { Jumlah } \\
\text { Responden }\end{array}$} & \multicolumn{2}{|c|}{ Nilai } & \multirow{2}{*}{$\begin{array}{c}\text { Rerata } \\
\text { Nilai } \\
\text { Selurul } \\
\text { Siswa }\end{array}$} \\
\hline & & Tertinggi & Terendah & \\
\hline Pretest & \multirow{2}{*}{20 orang } & $\begin{array}{c}60 \\
\text { (S9 dan } \\
\text { S11) }\end{array}$ & $\begin{array}{c}10 \\
(S 12)\end{array}$ & 37,5 \\
\hline Pasttest & & $\begin{array}{l}100 \\
\text { (S6 dan } \\
\text { S11) }\end{array}$ & $\begin{array}{c}70 \\
\text { (S18) }\end{array}$ & 85,175 \\
\hline
\end{tabular}

Hasil Uji Hipotesis

Dari hasil perhitungan uji normalitas dan homogenitas, diketahui bahwa hasil pretest dan posttest siswa berdistribusi normal dan memiliki varian yang homogen. Selanjutnya 
diuji perbedaan dua rerata antara hasil pretest dan hasil posttest. Uji perbedaan dua rerata tersebut menggunakan uji $t$ satu pihak yaitu uji pihak kanan berupa paired sample $t$ test berbantuan software SPSS 16.0 for wimdows dengan taraf signifikan $a=5 \%=0,05$. Dikatakan terdapat peningkatan nilai rerata setelah diberi perlakuan apabila $t_{\text {hitung }} \leq$ $t_{\text {tabel }}$. Sebaliknya, dikatakan tidak terdapat peningkatan nilai rerata setelah perlakuan apabila $t_{\text {hitung }}>t_{\text {tabel }}$.

Dari data hasil penelitian dengan $n=20$ diperoleh nilai rerata sebelum perlakuan adalah 37,5 dan nilai rerata setelah perlakuan adalah 85,175 . Selanjutnya, berdasarkan perhitungan dengan menggunakan SPSS 16.0 for windows diperoleh nilai $t_{\text {hitung }}=0,000$. Dengan $a=5 \%=0,05$ diperoleh $t_{\text {tabel }}=1,729$.

\section{Tabel 3.4. Output Hasil Perhitungan Uji $t$ Dengan SPSS}

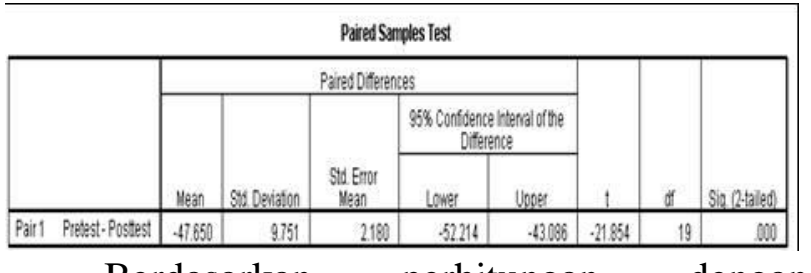

Berdasarkan perhitungan dengan menggunakan SPSS 16.0 for windows diperoleh data $t_{\text {hitung }} \leq t_{\text {tabel }}$, maka dapat disimpulkan bahwa $H_{0}$ ditolak dan $H_{\mathrm{a}}$ diterima. Sehingga hipotesis yang diajukan dalam penelitian ini adalah benar dan terbukti.

\section{PEMBAHASAN}

Proses pembelajaran dengan mengutamakan penggunaan metode perkalian latis sebagai satu treatment yang terbagi dalam 4 kegiatan yang ditujukan untuk mengatasi kesulitan siswa dalam menyelesaikan soal operasi perkalian dan kecemasan matematis diawali dengan memperkenalkan metode perkalian latis itu sendiri serta menjelaskan bagaimana cara kerja dari metode tersebut. Selanjutnya, peneliti memberikan latihanlatihan soal dari soal yang dilengkapi dengan kotak perkalian latis hingga tidak ada bantuan kotak perkalian latis yang semuanya tercantum dalam LKS yang dibagikan peneliti.

Selama proses penelitian, semua siswa terlihat lebih aktif, antusias dan semangat untuk dapat mennyelesaikan setiap soal operasi perkalian yang diberikan dengan menggunakan metode perkalian latis yang telah diperkenalkan oleh peneliti. Hal ini sejalan dengan pendapat Zubaidah, Margiati, dan Kresnadi (2015) yang menyebutkan salah satu kelebihan dari metode perkalian latis yaitu dapat merangsang siswa untuk lebih aktif dalam mengikuti proses belajar. Tidak jarang dari beberapa siswa ingin diberikan tambahan soal untuk dijadikan latihan kembali di rumah. Hal ini menunjukkan bahwa ada respon positif dari siswa untuk berusaha mengatasi kesulitannya dalam menyelesaikan operasi perkalian.

Untuk dapat melihat pengaruh dari penerapan lattice multiplication method untuk mengatasi kesulitan menyelesaikan operasi perkalian, peneliti melalukan uji perbedaan rerata dari hasil pretest dan posttest yang telah dilakukan.

Berdasarkan hasil penelitian pretest menunjukkan nilai tertinggi adalah 60 dan nilai terendah adalah 10. Setelah dilakukan analisis diperoleh nilai rerata 37,5. Pretest ini dilakukan oleh peneliti dengan tujuan untuk dapat mengetahui kemampuan awal siswa dalam menyelesaikan soal perkalian sebelum diberikan perlakuan yaitu berupa penerapan metode perkalian latis. Sedangkan pada hasil penelitian posttest menunjukkan nilai tertinggi adalah 100 , nilai terendah adalah 70 , dengan rerata nilai 85,175. Hal ini menunjukkan bahwa siswa yang diberikan perlakuan berupa penerapan metode perkalian latis memperoleh peningkatan hasil rerata dari tes awal sebelum diberikan perlakuan (pretest) sampai tes akhir setelah diberikan perlakuan (posttest).

Selanjutnya dari data analisis hasil penelitian pretest dan posttest dengan jumlah siswa 20 orang, dilakukan uji perbedaan dua 
rerata nilai dengan uji $t$ berbantuan SPSS 16.0 for windows yaitu paired sample t test untuk dapat mengetahui tingkat perbedaan rerata dari kedua hasil tersebut secara statistik. Berdasarkan perhitungan dengan menggunakan SPSS 16.0 for windows diperoleh nilai $t_{\text {hitung }}=0,000$. Dengan $a=5 \%=0,05$ diperoleh $t_{\text {tabel }}=1,729$ sehingga dapat dikatakan bahwa $t_{\text {hitung }} \leq t_{\text {tabel }}$. Oleh karena itu antara data pretest (sebelum perlakuan) dan posttest (setelah perlakuan) memiliki perbedaan yang signifikan. Jadi dapat disimpulkan bahwa $H_{0}$ ditolak dan $H_{\mathrm{a}}$ diterima yang berarti penerapan metode perkalian latis memiliki pengaruh yang signifikan untuk mengatasi kesulitan menyelesaikan operasi perkalian. Hal ini sejalan dengan pendapat Sugiyono (2017) yang mengatakan bahwa kriteria dalam menguji hipotesis yaitu jika $t_{\text {hitung }} \leq t_{\text {tabel }}$ maka $\mathrm{H}_{\mathrm{a}}$ diterima dan $\mathrm{H}_{0}$ ditolak, sedangkan jika $t_{\text {hitung }} \geq t_{\text {tabel }}$ maka $\mathrm{H}_{\mathrm{a}}$ ditolak dan $\mathrm{H}_{0}$ diterima. Sehingga, hipotesis yang diajukan dalam penelitian ini adalah benar dan terbukti.

\section{KESIMPULAN DAN SARAN}

\section{Kesimpulan}

Berdasarkan analisis hasil penelitian dan pembahasan yang telah dipaparkan sebelumnya, dapat disimpulkan bahwa penerapan metode perkalian latis memiliki pengaruh yang signifikan untuk mengatasi kesulitan menyelesaikan operasi perkalian. Dengan uji hipotesis menggunakan uji $t$ (paired sample $t$ test) berbantuan SPSS 16.0 diperoleh data $t_{\text {hitung }}=0,000$ dan dengan $a=5 \%=$ 0,05 diperoleh $t_{\text {tabel }}=1,729$ yang artinya $t_{\text {hitung }} \leq t_{\text {tabel }}$. Dengan demikian, maka $H_{0}$ ditolak dan $H_{\mathrm{a}}$ diterima. Dimana $H_{\mathrm{a}}$ berbunyi: Ada pengaruh penerapan lattice multiplication method dalam mengatasi kesulitan menyelesaikan operasi perkalian pada siswa kelas VIII SMPN 7 Pujut. Sehingga, hipotesis yang diajukan dalam penelitian ini adalah benar, terbukti, dan dapat diterima.

Saran
Bagi peneliti selanjutnya, perlu melakukan penyampaian yang lebih mendalam tentang pengenalan metode perkalian latis serta memberikan siswa lebih banyak lagi latihan soal dengan menggunakan soal-soal operasi perkalian yang lebih beragam agar hasil pembelajaran yang diinginkan lebih maksimal

\section{DAFTAR PUSTAKA}

Astrawan, I G B. 2014. Penerapan Model Pembelajaran NHT Dalam Meningkatkan Hasil Belajar Siswa Pada Mata Pelajaran IPA: Jurnal Kreatif Tadulako Online. 3(4): 227-242.

Lestari, Puji. 2017. Meningkatkan Kemampuan Pemecahan Masalah Segiempat Melalui Metode Inquiry Pada Siswa SMP Negeri 19 Mataram: Jurnal Ilmu Sosial dan Pendidikan. Vol. 1, No. 2.

Mujib, Abdul, dan Erik Suparingga. 2013. Upaya Mengatasi Kesulitan Siswa Dalam Operasi Perkalian Dengan Metode Latis. Dipresentasikan Dalam Seminar Nasional Matematika dan Pendidikan Matematika: Penguatan Peran Matematika dan Pendidikan Matematika Untuk Indonesia Yang Lebih Baik. Yogyakarta.

Musfiqon, H.M. 2012. Panduan Lengkap Metodelogi Penelitian Pendidikan. Jakarta: Prestasi Pustakaraya.

Rachman, N F., Syahrir., dan Puji Lestari. 2014. Penerapan Strategi PQ4R Dengan Penilaian Portofolio Untuk Menigkatkan Pemahaman Konsep Trigonometri Siswa SMA Negeri 1 Batu Layar: Jurnal Pendidikan Matematika. 3(2): 429-435.

Rahman, Ulfiani, Nursalam dan M. Ridwan Tahir. 2015. Pengaruh Kecemasan dan Kesulitan Belajar Matematika Terhadap Hasil Belajar Matematika Pada Siswa Kelas X MA Negeri 1 Watampone Kabupaten Bone. Makassar: Jurnal Matematika dan Pembelajaran. Vol. 3, No. 1. 
Runtukahu, J.Tombokan, dan Selpius Kandou. 2014. Pembelajaran Matematika Dasar Bagi Anak Berkesulitan Belajar. Yogyakarta: Ar-Ruzz Media.

Sugiyono. 2017. Metode Penelitian Pendidikan Pendekatan Kuantitatif, Kualitatif, dan $R \& D$. Bandung: Alfabeta.

Suryabrata, Sumadi. 2010. Metodelogi Penelitian. Jakarta: Rajawali Pers.

Susilo, Yudi, dan Siti Khadibah. 2013. Peningkatan Motivasi Belajar Siswa Melalui Model Pembelajaran Kooperatif Tipe Numbered Head Together (NHT) Materi Ajar Perbandingan dan Fungsi Trigonometri Pada Siswa Kelas X: MATHEdunesa. Vol. 2, No. 2.

Sutarto, dan Syarifuddin. 2013. Desain Pembelajaran Matematika. Yogyakarta: Samudra Biru.

Taniredja, Tukiran dan Hidayati Mustafidah. 2012. Penelitian Kuantitatif (Sebuah Pengantar). Bandung: Alfabeta.

Thoifah, I'anatut. 2015. Statistika Pendidikan Dan Metodelogi Penelitian Kuantitatif. Malang: Madani.

Zubaidah, Margiati dan Hery Kresnadi. 2015. Peningkatan Hasil Belajar Matematika Dengan Metode Lattice Di Kelas III Sekolah Dasar: Jurnal Pendidikan dan Pembelajaran. Vol. 4, No. 1. 